\title{
Planktonic Foraminiferal Biosatratigraphy of the Eocene - Oligocene Boundary at Sinjar Area, NW Iraq
}

\author{
Hiba A. Al-Rubai \\ Dept. Of Geology \\ College of Science \\ University of Mosul
}

\author{
Majid. M. Al-Mutwali \\ Dept. of Petro. and Refining Engineering \\ Coll. of Petro. Engineering and Mining \\ University of Mosul
}

(Received 18/3/2020 , Accepted 27/6/2020)

\begin{abstract}
The present study deals with the lithostratigraphy, biostratigraphy and chronostratigraphy of the Eocene- Oligocene boundary in three surface sections in Sinjar anticline, northwestern Iraq. Jaddala Formation composed of marl, marly limestone represents deep Eocene facies, Palani, and Tarjil formations represent Early and Late Oligocene sequences. Sixty-two planktonic foraminiferal species belonging to sixteen genera have been recognized which permit the recognition of four Zones; these are from older at the base:
\end{abstract}

Globorotalia opima opima Total- Range Zone (P21)

Globigerina ampliapertura partial- Range Zone (P20)

Pseudohastigerina micra Interval Zone (P 19)

Globigerinatheka subconglobata subconglobata Partial Range Zone (P11) (Part).

The Eocene- Oligocene boundary in Sinjar area represents disconformity surface, where the deposition ceased in the Middle Eocene (Lutetian) at the end of Jaddala Formation, then deposition started at the Upper Early Oligocene due to rapid wide transgression, leading to the deposition of Palani (Rupelian) and Tarjil (Chatian) formations, which consist of thinly laminated hard white-pale brown intercalation of marly limestone and marl beds.

Keyword: Biostratigraphy, Eocene-Oligocene boundary, Sinjar, Iraq.

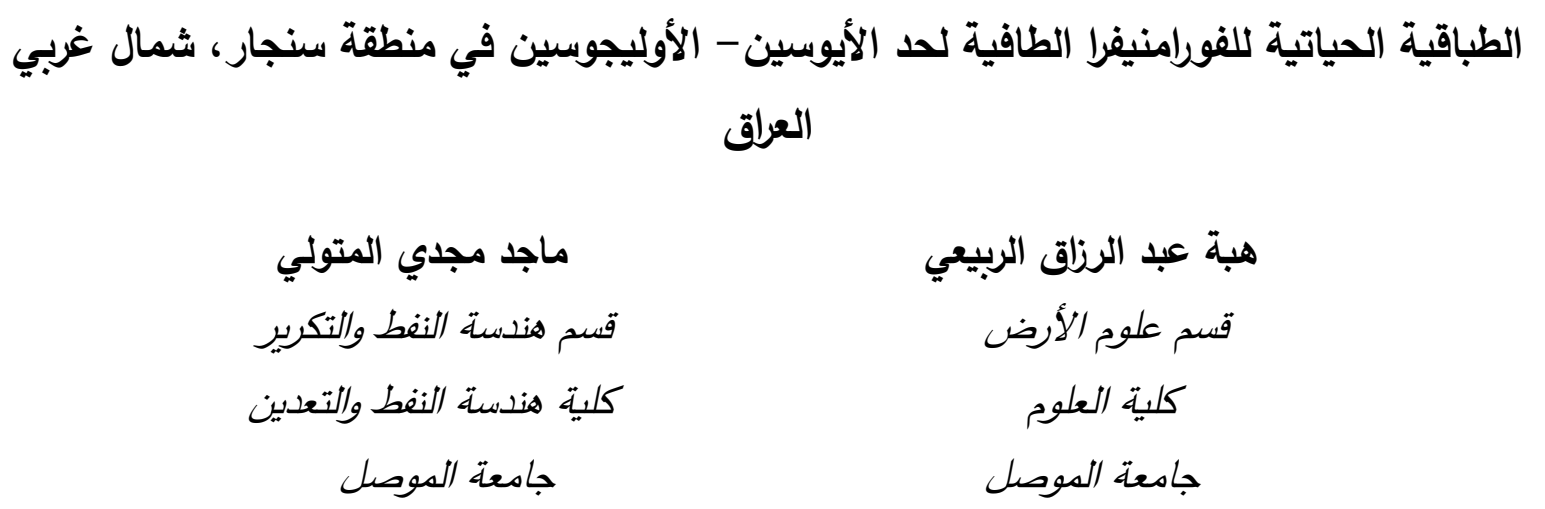




\section{المستخلص}

يمثل البحث الحالي دراسة طباقية صخرية وحياتية وزمنية لحد الأيوسين - الأوليجوسين في ثلاث مقاطع سطحية (مقطع جدالة ومقطع سنجار ومقطع شرف الدين) ضمن طية سنجار شمال غربي العراق. تمثلت تتابعات الأيوسين بصخور المارل والحجر الجيري المارلي العائد لتكوين جدالة المترسبة في بيئات بحرية عميقة، اما تتابعات الأوليجوسين المبكر فتعود لتكوين بلاني المؤلفة من الكونكلومريت والمارل والحجر الجيري المارلي، وتمثلت تتابعات الأوليجوسين الأوسط بصخور المارل والحجر الجيري المارلي العائد لتكوين تارجيل. تم تشخيص (62) نوعا وتحت نوع من انواع الفورامنيفرا الطافية تعود ل (16) جنساً . وأعتماداً على حشود الفورامنيفرا الطافية تم تحديد اربعة انطقة حياتية ضمن المقاطع المذكورة: النطاق الأول يقع ضمن تكوين جدالة بعمر الأيوسين الأوسط والنطاق الثاني بعمر اعلى الأوليجوسين المبكر متمثلاً بتكوين بلاني في حين حدد النطاقان النان

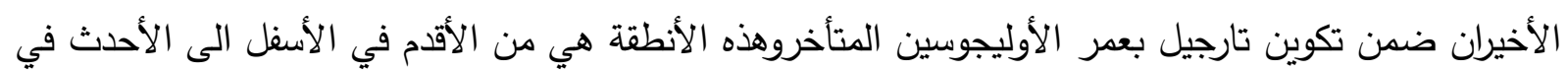

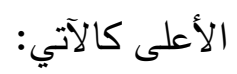

Globorotalia opima opima Total- Range Zone (P21)

Globigerina ampliapertura partial- Range Zone (P20)

Pseudohastigerina micra Interval Zone (P 19)

Globigerinatheka subconglobata subconglobata Partial- Range Zone (P11) (Part).

يمثل حد الأيوسين - الأوليجوسين في منطقة سنجار حداً لاتوافقيا اقليميا حيث توقف الترسيب في

الأيوسين الأوسط (اللوتيتيان) في اعلى تتابعات تكوين جدالة، ومن ثم ابتدأ طغيان بحري في اعلى الأوليجوسين


بحوالي 9 ملايين سنة. الكلمات الدالة: الطباقية الحياتية، حد الأيوسين - الأوليجوسين، سنجار ، العراق

\section{INTRODUCTION}

The Eocene - Oligocene boundary at Sinjar area is a discontinuity surface located between Jaddala Formation and the overlying Palani Formation and Tarjil Formation. The first description of Jaddala Formation was given by Henson in 1940 (Bellen et al., 1959), it's type section lies near Jaddala village on the southern limb of Sinjar anticline, fifteen kilometers to the west of Sinjar city, northwestern Iraq. According to Bellen et al. (op. cit), the Jaddala Formation consists of marl, marly limestone and chalky limestone, it has a wide distribution during Eocene age in Iraq extending into the Mesopotamian zone, foothill zone and into the northern and western parts of the stable shelf area (Jassim and Goff, 2006). Previous stratigraphic and paleontological studies indicate that Jaddala Formation was deposited in deep open marine basin during late early - late Eocene age (Buday, 1980; Al-Hashimi and Amer, 1985 and Al-Muwali, 1992), while its age restricted to late early - middle Eocene in Sinjar area (Elewi, 1982; Al-Mutwali and Al-Banna, 2002; Ismail, 2006; Al-Banna et al., 2010 and Al-Mutwali and Al-Sharbaty, 2013). According to Al-Hashimi and Amer (1985), Palani Formation is known in the low folded and Mesopotamian zones, 
including typical basinal facies rich in plankton foraminifera, which may be condensed and reduced to few meters in northwestern Iraq. Tarjil Formation occupies mostly the same areas of the former Palani Formation. The Eocene-Oligocene boundary is exposed along the both limbs of Sinjar anticline. Three sections for this boundary have been choosen for present study, two of them are located in the southern limb, Jaddala


third one is located in the northern limb Sharaf Al-Din section (N 41 ${ }^{\circ} 51^{\prime} 14^{\prime \prime}, \mathrm{E} 36^{\circ}$ 26' 03") (Fig.1).

The purpose of this paper is: (1) to give a detailed lithological description to the exposed studied sections of the Eocene-Oligocene boundary, which appears very clear in the study area due to the indications of discontinuity and erosion at the top of Jaddala Formation; and (2) to study the planktonic foraminiferal biostratigraphy through this boundary in order to give accurate age determination.

\section{MATERIALS AND METHODOLOGY}

The re-established chronostratigraphic framework for the studied units were based on planktonic foraminiferal zonation of Toumarkine and Luterbacher (1985) and Berggren et al. (1995). To achieve these work goals, three outcrops have been selected and utilized to identify the lithological composition and microfossils content. More than (68) rock samples were collected from the studied sections for planktonic foraminiferal study, about (30) g have been taken from each sample for foraminiferal analyses using classical method for washing (piking method).



Fig.1: Location map of the studied sections (modified from Al-Mutwali and Al-Sharbaty, 2013). 


\section{LITHOLOGICAL DESCRIPTION}

The present study includes Eocene-Oligocene sequences represented by Jaddala, Palani and Tarjil formations in three exposed sections (Jaddala, Sinjar and Sharaf AlDin). The studied sections are described lithologically based on field inspection. The lithological description started from the base to the top of each section:

1-Jaddala section: The total studied thickness of this section is $(27.5 \mathrm{~m})$, the studied thickness of the uppermost part of Jaddala Formation is (8) m, represented by(7) $\mathrm{m}$ sequence of white-yellow marly limestone beds, with medium hardness containing burrows of Thalassinoides which increasing upward, overlain by thinly laminated pale grey marl bed of $(1 \mathrm{~m})$ thickness with high density of Thalassinoides burrows. Palani Formation (4.5m thick) overlays Jaddala Formation unconformably, where it started by a basal conglomerate bed which is $(30 \mathrm{~cm})$ thick, it consists of extraclasts of chert, glauconite, magnetite, hematite, and sedimentary rock fragments, with mollusca shells and echinoid fossils, followed by white-yellowish limestone bed (50 $\mathrm{cm}$ thick) then light gray friable marl bed $(1 \mathrm{~m})$ thick. These beds contain detritus of chert, glauconite and iron oxides showing fining-upward grain size, with some transported litoclasts (Fig. 2). Upwards comes intercalation of marl and marly limestone beds about $(2.5 \mathrm{~m})$ thick continued towards the end of the Palani Formation. The studied (15 m thick) Tarjil Formation overlays Palani Formation conformably consisting of $3 \mathrm{~m}$ thick pale brown marly limestone and $12 \mathrm{~m}$ thick alternation of hard marly limestone and marl.
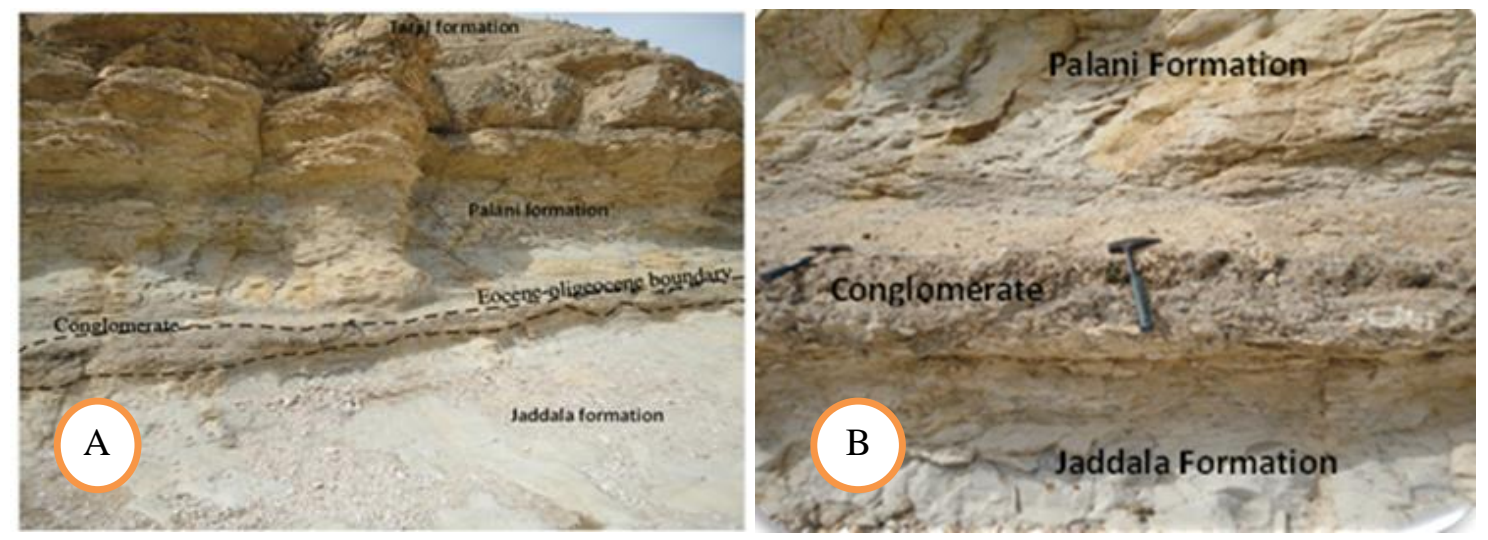

Fig.2: Eocene-Oligocene boundary at Jaddala section. (A) View of the outcrop showing the formations below and over this boundary. (B) Close-up photo showing the distinctive conglomerate bed in the field between Jaddala and Palani Formations.

2- Sinjar section: The total studied thickness of this section is $(15.5 \mathrm{~m})$ including (1 $\mathrm{m})$ from the uppermost part of Jaddala Formation, $(4 \mathrm{~m})$ Palani Formation and (10.5 m) Tarjil Formation. Jaddala Formation is composed of light brown marly limestone bed, while Palani Formation overlaying Jaddala Formation unconformably consists of $(2 \mathrm{~m})$ soft white - pale grey chalky limestone bed which formed of sandy size carbonate particles containing some trace fossils like Skolithos and planolites (Figs.3\&4). Also there are sedimentary structure in a form of cross bedding, followed by $(2 \mathrm{~m})$ pale brown thinly laminated marly limestone bed. Tarjil 
Formation consist of thinly laminated hard white-pale brown intercalation of marly limestone and marl beds.

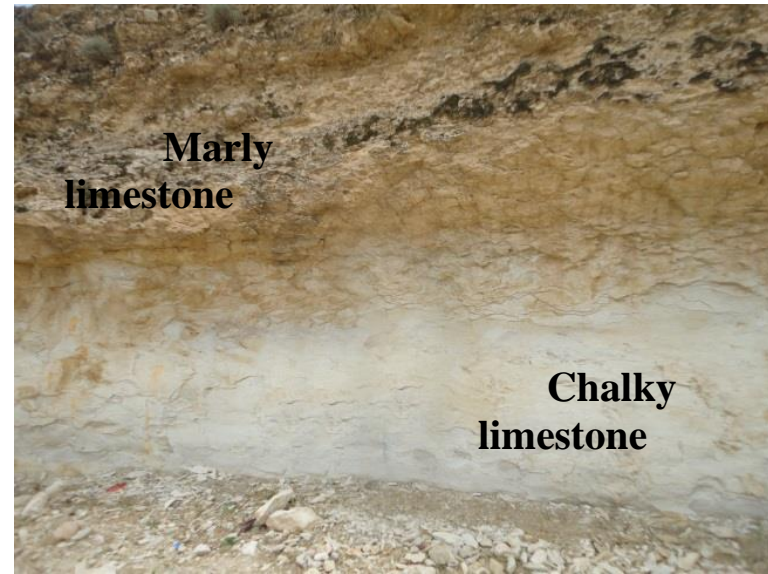

Fig. 3: The white soft chalky limestone bed $(2 \mathrm{~m}$. thick) at the base of Palani Formation (Early Oligocene) in Sinjar section.

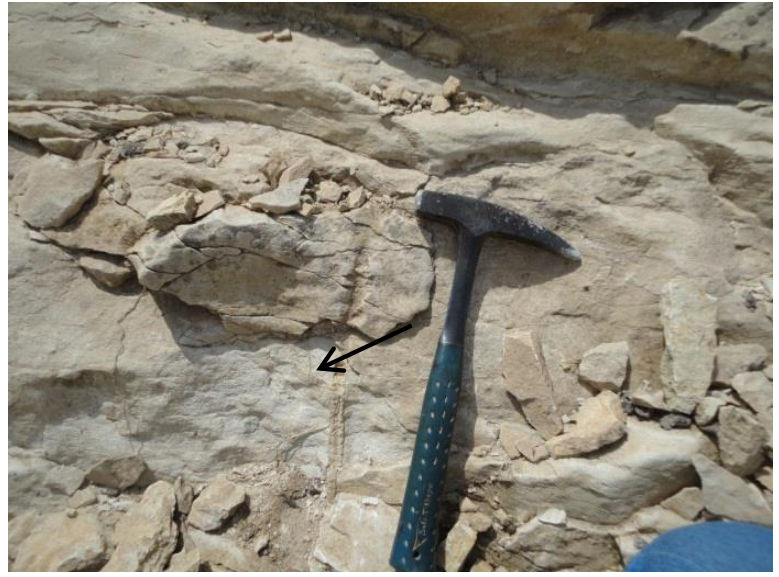

Fig.4: Skolithos burrow in the chalky limestone bed at the base of Palani Formation (Early Oligocene) in Sinjar section.

3- Sharaf Al-Din section: The total studied thickness of this section is $(81 \mathrm{~m})$ including Jaddala Formation (42 m), Palani Formation (11 m) and Tarjil Formation $(28 \mathrm{~m})$. Jaddala Formation is mainly composed of intercalation of pale grey marl and pale brown marly limestone for the lower $35 \mathrm{~m}$, and then appears thinly bedded marl bed ( $1 \mathrm{~m}$ thick), after that, a sequence of pale brown marly limestone continues to the end of the formation. The Jaddala Formation terminates by a conglomerate bed (3 cm thick) (Figs.5\&6), which contains fragments of chert and iron oxides. Unlined cylindrical vase- shaped domiciles appear within this bed, casts and molds of Pelecypoda shells mantle its upper surface, which may be the causative for these dwelling traces. Palani Formation overlays Jaddala Formation unconformably, where it is formed of repetition of marl and marly limestone. Tarjil Formation is also composed of repetition of pale grey marl and pale brown marly limestone. The separation between Palani Formation and Tarjil Formation deposits in Sharaf AlDin section is difficult because of the similarity in lithofacies in the two formations, but it seems that the deposits of Tarjil Formation are more hardened.

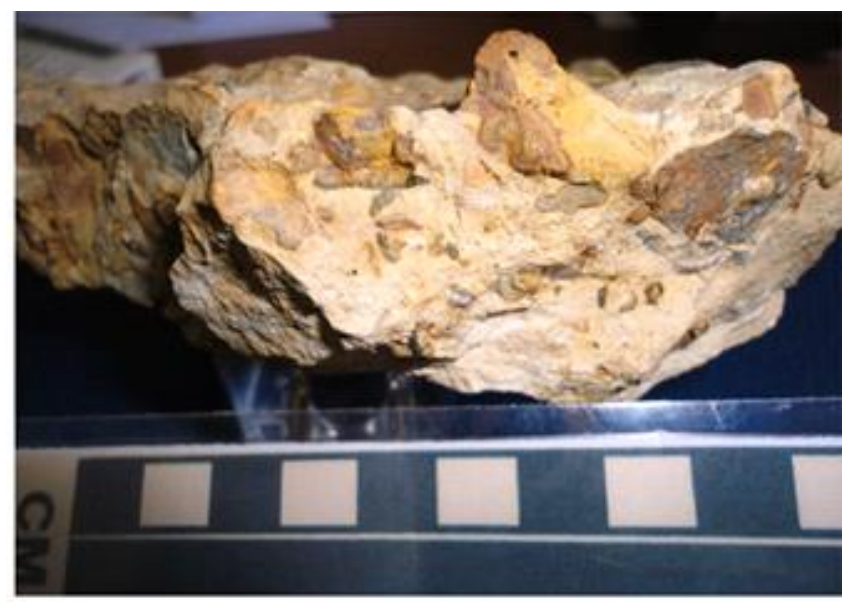

Fig.5: Vertical section of thin limestone bed appears at the Eocene-Oligocene boundary at Sharaf Al- Din section containing boring and tier dwelling structures filled by Iron oxides. 


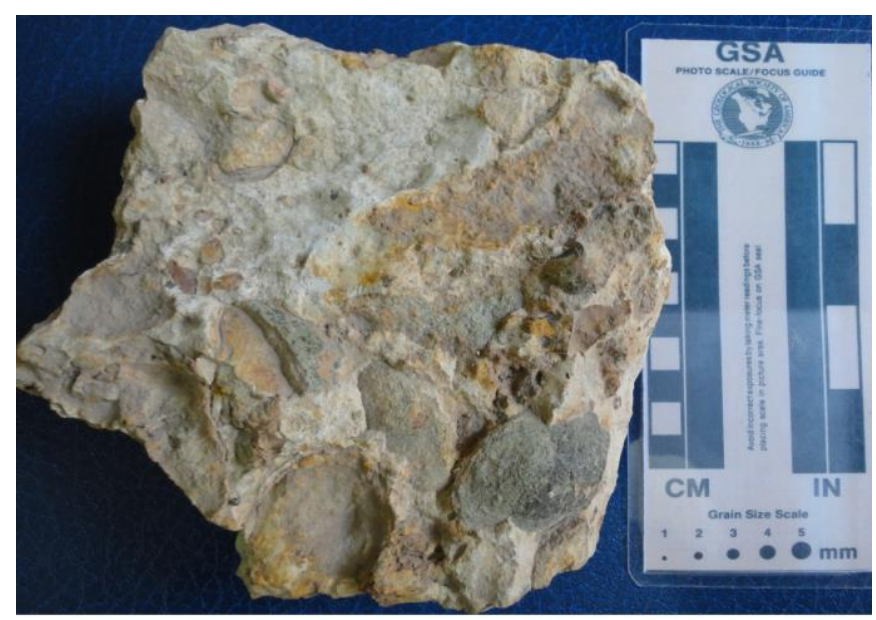

Fig.6: The upper surface of the same thin limestone bed which appears at the EoceneOligocene boundary at Sharaf Al-Din section plastered by Pelecypoda (oysters) representing a hardground disconformity surface.

\section{BIOSTRATIGRAPHY}

The biostratigraphic resolution obtained from the study of planktonic foraminifera of the Eocene-Oligocene successions (Jaddala, Palani and Tarjil formations). The Eocene - Oligocene rocks exposed in the Sinjar area consist of deepmarine carbonates. Washed residues from these rocks were investigated for common diverse planktonic foraminifera to be used as biostratigraphic tools for investigating the age of the studied sequences of Jaddala, Palani and Tarjil formations. The planktonic foraminifera are preserved very well, but vary from abundant in the Jaddala and Palani formations to common in the Tarjil Formation. The systematic investigation of planktonic foraminifera enabled us to identify (62) species and subspecies belonging to (16) genera in the studied sections, the stratigraphic distribution of these planktonic foraminiferal assemblages permits the recognition of four biozones (Figs.7, 8\&9). P11 in the Jaddala Formation, P19 in the Palani Formation and P20\&P21 in the Tarjil Formation, the thickness of these zones in the studied sections are shown in (Fig.10). These zones are correlated with similar ones established by other authors as shown in (Fig. 11). The four recognized zones are described in ascending order as follows:

\section{1- Globigerinatheka subconglobata subconglobata Partial - Range Zone (P11) (Part)}

Definition: Partial range with zonal marker from first occurrence of Globigerinatheka mexicana mexicana to last occurrence of Morozovella aragonensis.

Age: Middle Eocene (Lutetian)

Remarks: This zone is defined in the upper part of Jaddala Formation. The lower boundary of this zone is not included in this study; the top of this zone is well defined by the last occurrence of $M$. aragonensis and other Middle Eocene planktonic foraminiferal genera belonging to Turborotalia, Acarinina, Truncorotaloides, Globigerinatheka, Hantkenina and Morozovella. Common specimens of the nominal taxon, as well as Tub characterize this zone. frontosa, A bullbrooki, Tub. possagnoensis, A. spinuloinflata, Trun. rohri, Glgthk. mexicana mexicana, S. 
eocaena, Trun. topilensis, A. broedermanni, P. inaequispira, S. cryptomphala; S. hagni; M. spinulosa, M. aragonensis, M. lehneri, H. dumblei, A. mathewsa .

\section{2- Pseudohastigerina micra Interval Zone (P 19)}

Definition: Biostratigraphic interval is characterized by the range of the nominate taxon between the last occurrence of Middle Eocene planktonic foraminiferal species belonging to Turborotalia, Acarinina, Truncorotaloides, Globigerinatheka, Hantkenina and Morozovella at the base and the last occurrence of the nominate taxon at the top.

Age: Upper Early Oligocene (Rupelian)

Remarks: This zone is restricted to Palani Formation, where its lower boundary represents the unconformable surface between Jaddala Formation (Middle Eocene) and Palani Formtion (Early Oligocene), while its upper boundary represents the conformable contact between Palani Formation and Tarjil Formation. The hiatus between Eocene-Oligocene deposits is designated by the absence of the following zones: M.lehneri Zone (P12), O.beckmanni Zone (P13), Trun. rohi Zone (P14), Glgthk. semiinvoluta Zone (P15+ Lower part of P16), Tub. cerroazulensis Zone (P17 + Upper part of P16) and Cs. chipolensis Zone (P18). The species Cs. Chipolensis is not recorded in this study so we depend on the last occurrence of the index species Psh.micra to delineate the upper boundary of Psh.micra Zone corresponding to the Mancini and Waters (1986). Common specimens of these taxa G.ampliapertura, Grt. Increbescens, G. tripartite, G. pseudoampliapertura, G. pseudovenezuelana Blow \& Banner; Grt. opima nana, Globorotaloides suteri, G. prab, characterize this zone. praebulloides, G. ouachit. ouachitaensis, G. ouachita gnaucki, G. ciperoensis angulisuturalis, G. prab. occlu Gats. dissimilis, G. venezuelana, S. angiporoides.

\section{3- Globigerina ampliapertura partial- Range Zone (P20)}

Definition: Biostratigraphic interval is characterized by the partial range of the nominate taxon between the last occurrence of Psh. micra at the base and first occurrence of Grt. opima opima at the top.

Age: Late Oligocene (Chattian).

Remarks: This zone is recorded from the base of Tarjil Formation. The boundaries of this zone are corresponding to Bolli, 1957; Bolli \& Premoli Silva, 1973; Stainforth et al., 1975; Bolli \& Saunders, 1985; Spezzaferri \& Premoli Silva, 1991; Lidz \& McNeill, 1995. The following planktonic foraminifera characterize this zone : $G$. ampliapertura, G.venezuelana, G. ouachit. Ouachitaensis G.pseuoamplipertura, Grt. opima nana, Gats. unicavus, Globorotoloides suteri , G. prab. praebulloides, G. ouachit. ouachitaensis, G. ouachit gnaucki, G. prab. occlusa, S. yeguaensis, Dentoglobigerina galavisi, S. angipovoides, G. selli, G. euapertura, G. venezuelana .

\section{4- Globorotalia opima opima Total- Range Zone (P21)}

Definition: Biostratigraphic interval is characterized by the total range of the nominate taxon.

Age: Late Oligocene (Chattian). 
Remarks: This zone is recorded from Tarjil Formation and it is characterized by common specimens of the nominal taxon, as well as $G$. ciperoensis ciperoensis, $G$. venezuelana, Dentoglobigerina galavisi, S. yeguaensis, G. prab occlusa, $G$. ouachitaensis ouachitaensis, G. prab. praebulloides, Cats. unicavus, Grt. opima nana, G. ciperoensis angustiumbilicata, G. euapertura.

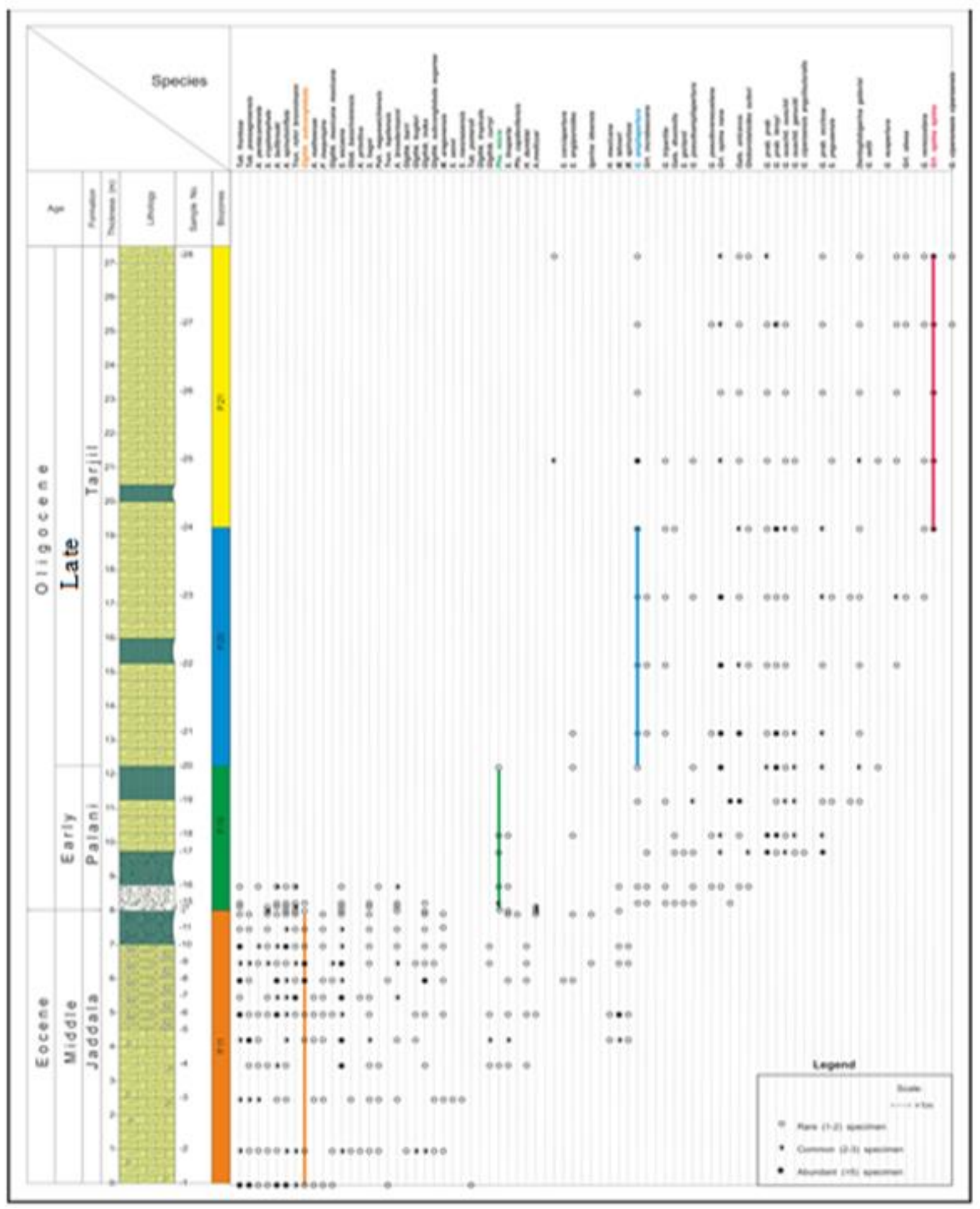

Fig. 7: Distribution of planktonic foraminifera and biostratigraphic zones in Jaddala section. 




Fig. 8: Distribution of planktonic foraminifera and biostratigraphic zones in Sinjar section. 
Hiba A. Al-Rubai and Majid. M. Al-Mutwali

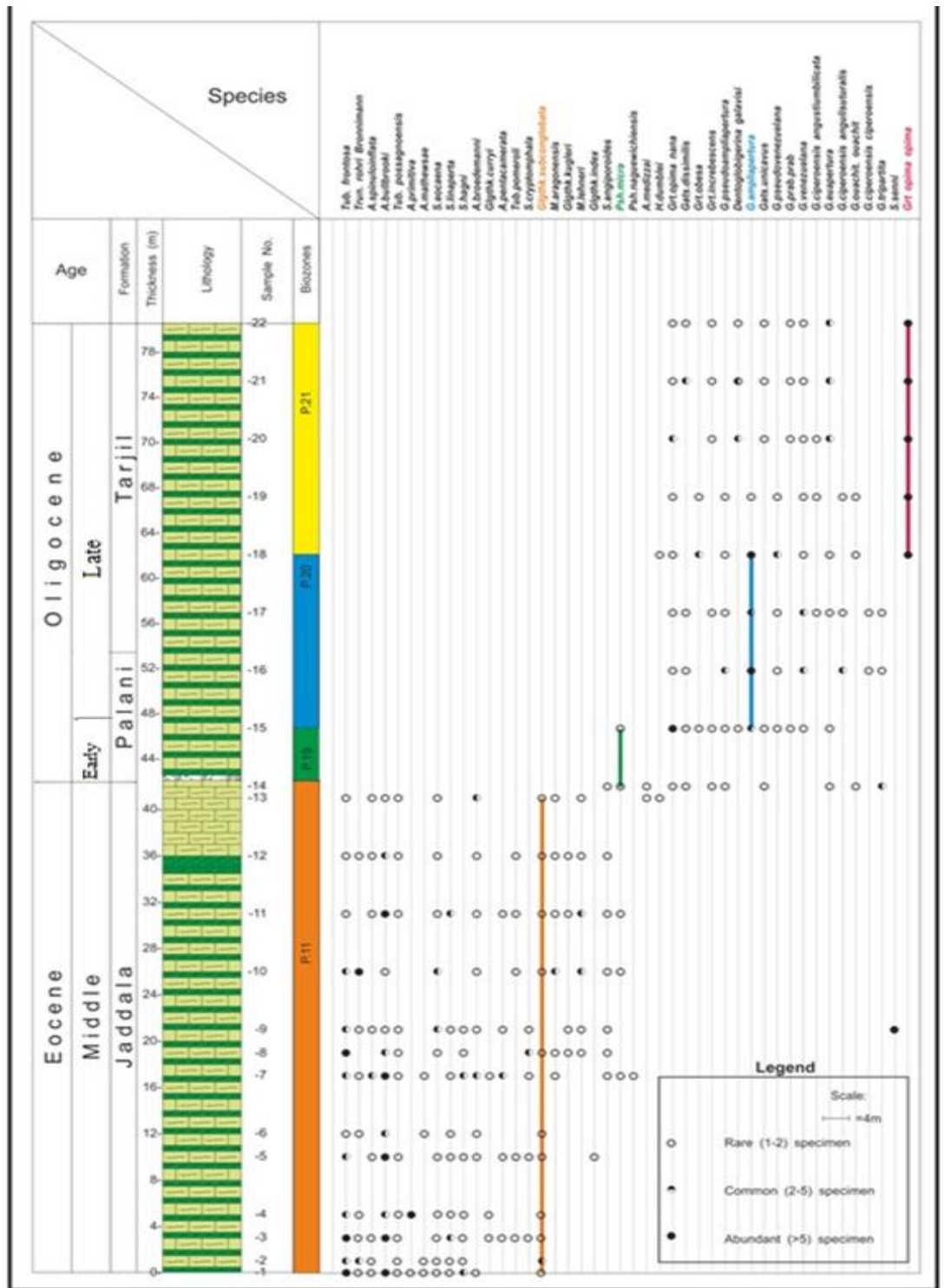

Fig. 9: Distribution of planktonic foraminifera and biostratigraphic zones in Sharaf Al-Din section.

\begin{tabular}{|c|c|c|c|c|c|c|c|}
\hline $\begin{array}{l}\text { Age }(\mathrm{Ma}) \\
\text { After } \\
\text { Gradstein } \\
\text { etal., } \\
2004\end{array}$ & $\cdot \stackrel{\mathscr{Q}}{\bar{E}}$ & 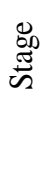 & Formations & $\begin{array}{l}\text { Planktonic } \\
\text { foraminiferal zones }\end{array}$ & $\begin{array}{l}\text { Jaddala } \\
\text { Section }\end{array}$ & $\begin{array}{l}\text { Sinjar } \\
\text { Section }\end{array}$ & $\begin{array}{c}\text { Sharaf } \\
\text { Al- } \\
\text { Din } \\
\text { Section }\end{array}$ \\
\hline \multirow{4}{*}{$\begin{array}{c}34.0 \\
35.0 \\
46.0\end{array}$} & \multirow{3}{*}{$\begin{array}{l}\stackrel{0}{0} \\
\stackrel{0}{0} \\
.000 \\
0\end{array}$} & \multirow[b]{2}{*}{ 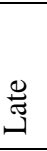 } & \multirow{2}{*}{ Tarjil } & $\begin{array}{c}\text { Grt.opima opima } \\
\text { (P21) }\end{array}$ & $8 \mathrm{~m}$ & $4 \mathrm{~m}$ & $18 \mathrm{~m}$ \\
\hline & & & & $\begin{array}{c}\text { G.ampliapertura } \\
\text { (P20) }\end{array}$ & $7 \mathrm{~m}$ & $7 \mathrm{~m}$ & $15 \mathrm{~m}$ \\
\hline & & $\underset{\overparen{Z}}{\overparen{\Xi}}$ & Palani & Psh.micra (P19) & $4.5 \mathrm{~m}$ & $3.5 \mathrm{~m}$ & $6 \mathrm{~m}$ \\
\hline & 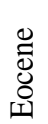 & $\frac{0}{\stackrel{0}{0}}$ & Jaddala & $\begin{array}{c}\text { Glgthk.subconglobata } \\
\text { (P11) }\end{array}$ & $8 \mathrm{~m}$ & $1 \mathrm{~m}$ & $42 \mathrm{~m}$ \\
\hline
\end{tabular}

Fig.10: Age and thickness of planktonic foraminiferal zones in the studied sections. 


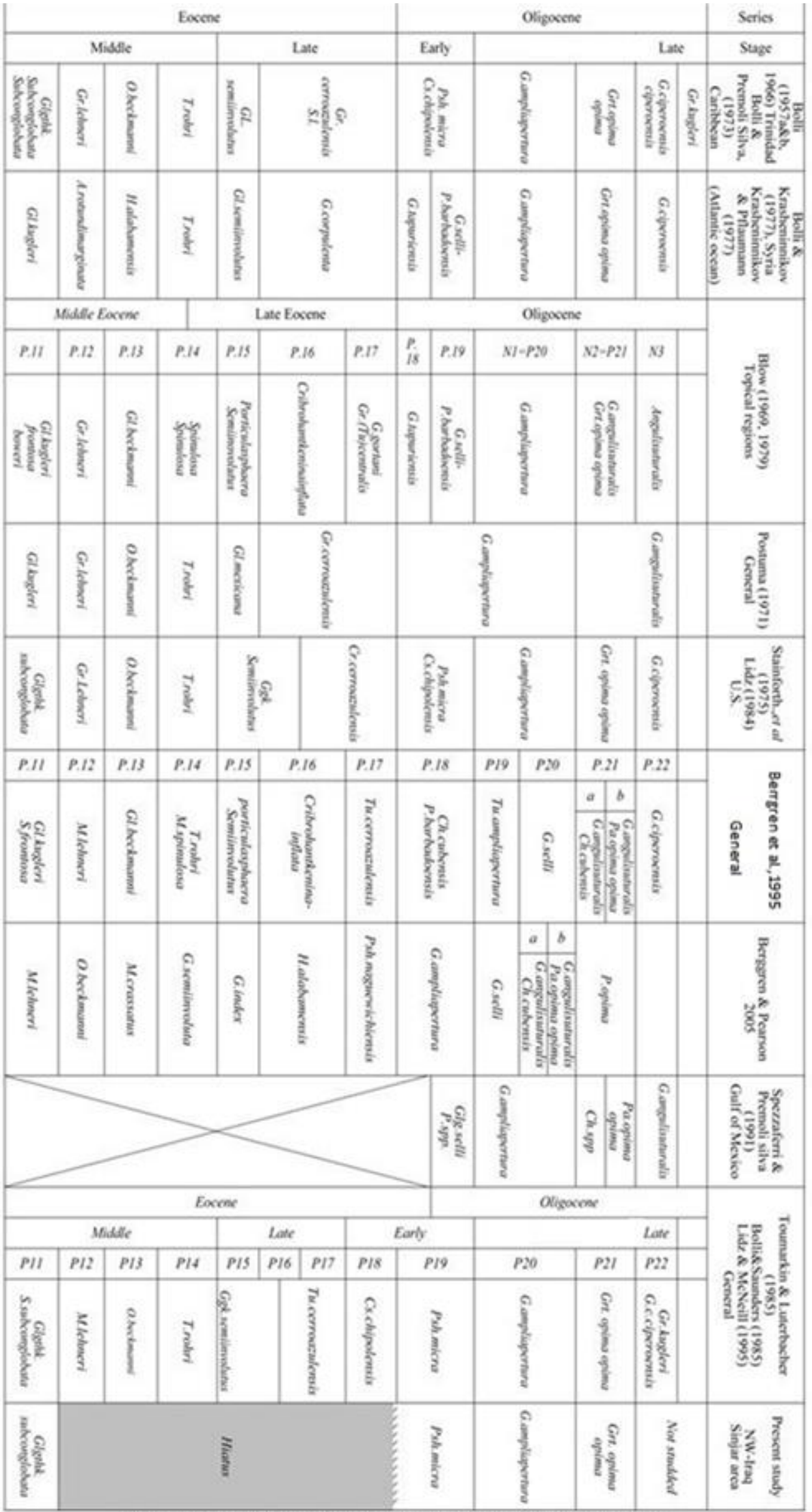

Fig. 11: Correlation of planktonic foraminiferal biozones 


\section{CONCLUSIONS}

1- The Eocene - Oligocene boundary in Sinjar area is a discontinuity surface located between Jaddala Formation of Early - Middle Eocene age and the overlying Palani Formation of Early Oligocene age and Tarjil Formation of Late Oligocene age.

2- The Jaddala Formation is composed of marl and marly limestone representing the deposition in deep marine environments.

3- The Palani Formation in Jaddala section started with a conglomerate bed overlain by marl and marly limestone beds, while in Sinjar section it started by chalky limestone bed.

4- The Tarjil Formation consists of thinly laminated hard white-pale brown intercalation of marly limestone and marl beds.

5- Sixty-two planktonic species and subspecies belonging to sixteen genera have been recognized within the studied sections, which permits the recognition of four zones. These are from older at the base:

Globorotalia opima opima Total- Range Zone (P21)

Globigerina ampliapertura partial- Range Zone (P20)

Pseudohastigerina micra Interval Zone (P 19)

Globigerinatheka subconglobata subconglobata Partial - Range Zone (P11) (Part).

6- The stratigraphical and paleontological investigation of the Eocene -Oligocene boundary in Sinjar area indicates that the sedimentation stopped during the Middle Eocene (Lutetian) (Zone P11), which is represented by the uppermost part of Jaddala Formation. This event made this surface a regional disconformity surface and sequence boundary of type 1, that caused a regional hiatus (about $9 \mathrm{My}$ ) before it started again at the Early Oligocene (Rupelian) (P19).

\section{REFERENCE}

Al-Banna, N.Y. and Al-Mutwali, M.M., 2002: Microfacies, sequence stratigraphy \& cooling events of Oligocene (Palani \&Tarjil formations) at Sinjar area, Northwest Iraq.Iraqi, J. of Erth Sci., V.2, No. 2, pp. 48-58.

Al-Banna, N.Y., and Al-Mutwali, M.M., Ismail, N. R., 2010: Oligocene stratigraphy in the Sinjar Basin, NW Iraq.Geo Arabia, V.15, No.4, pp.17-44.

Al-Hashimi, H.A., J and Amer, R.M., 1985: Tertiary microfacies of Iraq. State Org. Min. Direc.Gene.Geol. Surv. Min. Investig Baghdad, 56 p, 159 plates.

Al-Mutwali, M. M., 1992: Foraminifera, Stratigraphy and Sedimentology of the Upper Cretaceous. Lower Tertiary in selected boreholes around KhleisiaAnah- ramadi area. Unpublished PhD. thesis, University of Mosul, Mosul-Iraq.300p.

Al-Mutwali, M. M and Al-Banna, N.Y., 2002: Planktonic foraminiferal biostratigraphy of the Oligocene (Palani \&Tarjil formations), Sinjar area. Northwestern Iraq. Raf. J. of Sci., V.13 No.4, pp. 70-80 
Al-Mutwali, M. M and Al-Sharbaty, I,S. 2013: Biostratigraphy of Planktonic Foraminifera of Jaddala Formation (Eocene), Bara area, North western Iraq. Iraqi Journal of Earth Science Vol. 13, No. 2 , pp.67- 84,2013.

Bellen, W. A., Dunnington, H.V., Wetzall, R. and Morton, D. M. 1959: Laxique stratigraphique international Asia fascicule 10a-Iraq. Paris, 333P.

Berggren, W.A., and Pearson, P.N., 2005: A revised tropical to subtropical planktonic foraminiferal zonation of the Eocene and Oligocene: Journal of Foraminiferal Research, V.35, p.279- 298.

Berggren, W.A., Kent, D. V., Swisher, I. C. C., and Aubry, M.-P., 1995: A revised Cenozoic geochronology and chronostratigraphy, In Berggren, W.A., Kent, D.V., Aubry, M.-P., and Hardenbol, J. (eds.), Geochronology, Time Scales and Global Stratigraphic Correlations: Society of Economic Paleontologists and Mineralogists Special Publication, V. 54, p. 129-212.

Blow, W.H., 1969: Late Middle Eocene to recent planktonic foraminiferal biostratigraphy proceeding. 1st.Intren. Conf. Microfossils Geneva, 1967. 1, pp. 199-421.

Blow, W. H., 1979: The Cainozoic Globigerinida: E.J. Brill, Leiden, 1413 p.

Bolli, H. M., 1957a: Planktonic foraminifera from the Eocene Navet and San Fernando Formations of Trinidad, B. W. I. Bull. U.S. Nat. Mus., 215, pp.155-172.

Bolli, H. M., 1957b: Planktonic foraminifera from the Oligocene-Miocene Cipro and Lengua Formations of Trinidad, B. W. I. Bull. U.S. Nat. Mus., 215, pp.97-123.

Bolli, H. M., \& Premoli Silva, I., 1973: Oligocene to Recent Planktonic foraminifera \& stratigraphy of the Leg (15) Sites in the Caribbean Sea. In: Edgar, N. T. et al., Initial Rep. DSDP, Washington. D.C., U.S. Govt. Printing office, 15, pp. 475479.

Bolli, H.M.and Krasheninnikov, V.A., 1977: Problems in Paleogene and Neogene correlation based on planktonic foraminifera. Micropaleontology, V 23, No.4, pp. $436-452$.

Bolli, H. M. \& Saunders, J.B., 1985: Oligocene to Holocene low latitude Planktonic foraminifera. In: Bolli, H. M., Saunders, J. B.\& Perch Nielsen, K.(eds.), Plankton Stratighraphy.Cambridge Univ. Press pp.155-262.

Buday, R.T., 1980: The regional geology of Iraq, 1, stratigraphy and paleogeography, Kassab, I.I. M. \& Jassim, S.Z. (ed). SOM, Baghdad, 445P.

Elewi, A.H., 1982: Stratigraphical and paleontological studies on some Eocene rocks in northern Iraq. (unpublished M.sc.Thesis) Cairo univ. 197 p.

Gradstain, F.M., Ogg, J.G., Smith, A.G. Bleeker, W. \& Lourens, L.J.,2004: A new Geological time scale with special reference to Precambrian \& Neogene. Episodes, Articles, V. 27, No. 2, pp. 83- 100.

Ismail, N.R. 2006: Stratigraphical and sedimentological studies of the Middle Eocene - Early Miocene succession in Sinjar Basin, northwestern Iraq. Unpublished PhD thesis, University of Mosul, Iraq, 222 p. 
Jassim, S.Z. and Goff, J.C., 2006: Geology of Iraq. Published by Dolin, Prague and Moravian Mus. Brno, 341P.

Krasheninnikov, V.A.\&Pflaumann, U.,1977: Zonal stratigraphy and planktonic foraminifera of Paleogene deposits of the Atlantic Ocean to the west of Africa (DSDP) Leg41. In Lanceolot, Y.Seibold, E.,et al.,Initial Rep.41,pp.581-611.

Lidz, B.H.,1984: Oldest (Early Tertiary) subsurface carbonate rocks of the St. Croix, U.S. Virgin, Revealed in a Turbidite-Mudball. J. Foram. Res., V.14, No.3, pp.213-227

Lidz, B.H., \& Mc Neill, O.F., 1995: Reworked Paleogene to Early Neogene Planktonic foraminifera: implications of an intriguing distribution at a Late Neogene prograding margin, Bahamas. Marine Micropaleo.25, p. 221-268.

Mancini, E.A., and Waters, L.A., 1986: Planktonic foraminiferal biostratigraphy of Upper Eocene and Lower Oligocene strata in southern Mississippi and Southwestern and South-Central Alabama. Journal of Foraminiferal Research, V.16, p.24-33.

Postuma , J.A., 1971 : Manual of planktonic foraminifera . Elsevier pub., Amesterdam, p. $1-420$.

Spezzaferri, S.\& Premoli Silva, I.,1991: Oligocene planktonic foraminiferal biostratigraphy and paleoclimatic interpretation from Hole538A, DSDP Leg77, Gulf of Mexico.Palaeogeo. Paleocl.Paleoeco.83, pp.217-263.

Stainforth, R. M., Lamb, J. L., Luterbacher, H., Beard, J. H., \& Jeffords, R.M., 1975: Cenozoic Planktonic foraminiferal zonation \& characteristies of index forms. Univ. of Kansas Plaeont. Coutr., Article, 62, 425P.

Toumarkine, M., and Luterbacher, H.-P., 1985: Paleocene and Eocene Planktic Foraminifera, In Bolli, H.M., Saunders, J.B., and Perch-Nielsen, K. (eds.), Plankton Stratigraphy: Cambridge University Press, Cambridge, p. 87-154. 


\section{PLATE (1)}

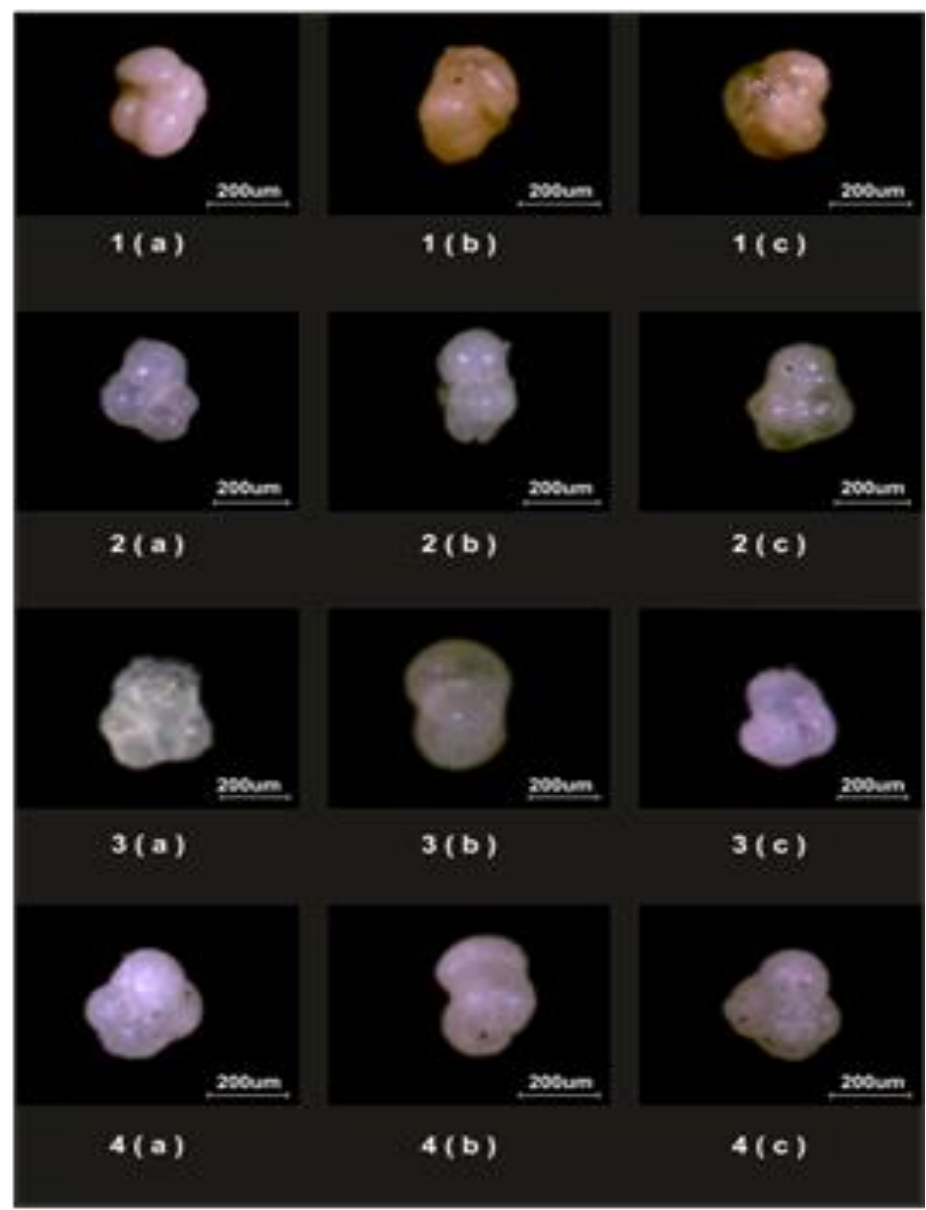

Figs. 1a-c: Globorotalia increbescens (Bandy,1949).

1a: Umbilical side, Sinjar section, Sample No.4.

1b: Side view, Sinjar section, Sample No.8.

1c: Spiral side, Sinjar section, Sample No.6.

Figs. 2a-c: Globorotalia obesa Bolli,1957b.

2a: Umbilical side, Jaddala section, Sample No.27.

2b: Side view, Jaddala section, Sample No. 27.

2c: Spiral side, Jaddala section, Sample No. 23.

Figs. 3a-c: Globorotalia opima nana Bolli $1957 \mathrm{~b}$.

3a: Umbilical side, Jaddala section, Sample No.19.

3b: Side view, Sinjar section, Sample No.9.

3c: Spiral side, Sinjar section, Sample No.9.

Figs .4a-c: Globorotalia opima opima Bolli1957 b.

4a: Umbilical side, Jaddala section, Sampl No. 25.

4b: Side view, Jaddala section, Sample No. 25.

4c: Spiral Side, Sinjar section, Sample No. 17.

(bar scale : $1 \mathrm{~cm}=200 \mathrm{um}$ ) 
PLATE (2)

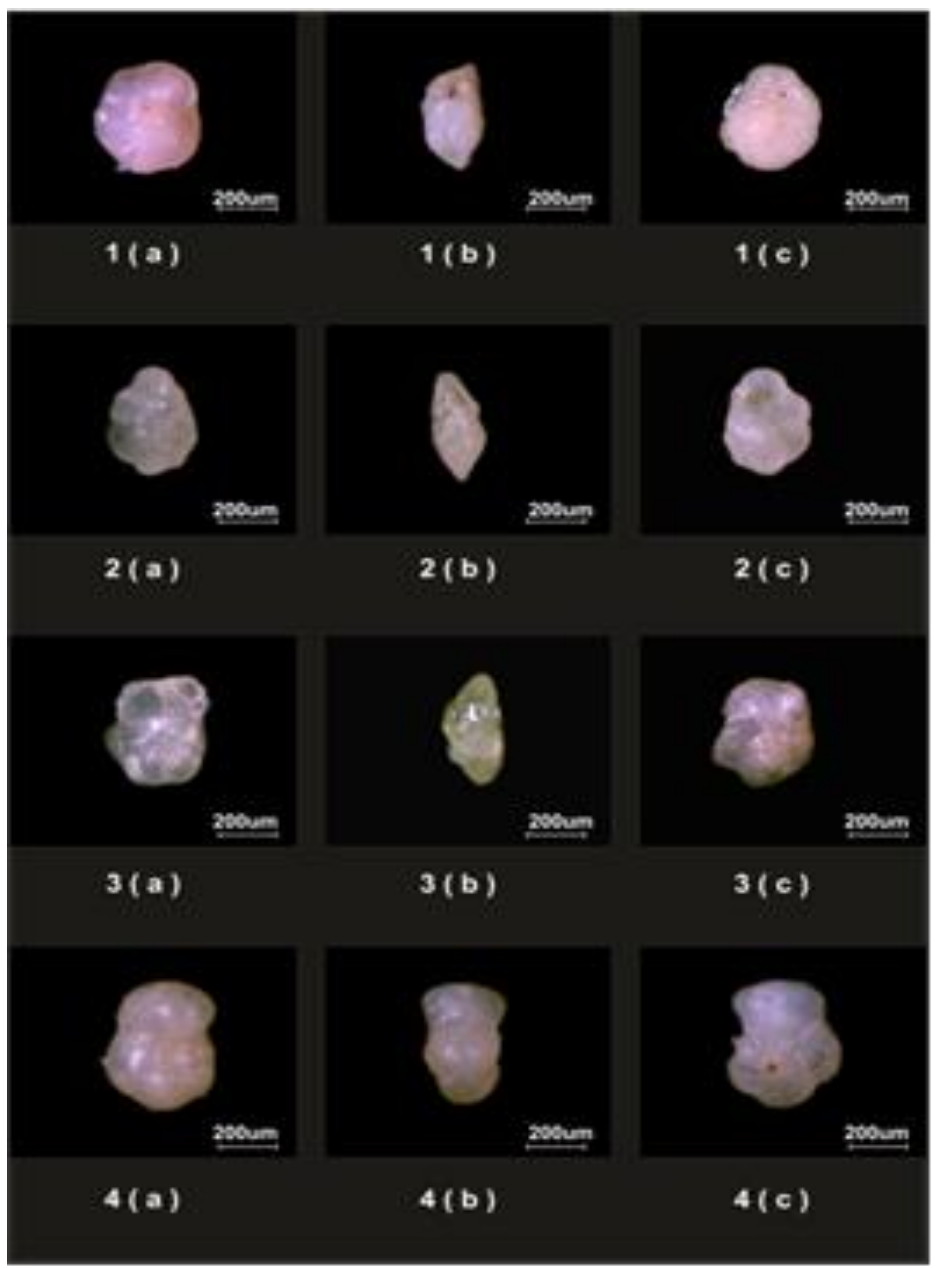

Figs.1a-c: Morozovella aragonensis (Nuttall,1930).

1a: Umbilical side, Jaddala section, Sample No. 4.

1b: Side view, Jaddala section, sample No. 2.

1c: Spiral side, Jaddala section, Sample No. 2.

Figs. 2a-c: Morozovella lehneri (Cushman \& Jarvis,1929).

2a: Umbilical side, Jaddala section, Sample No. 6.

2b: Side view, Jaddala section, Sample No.6.

2c: Spiral side, Jaddala section, Sample No.6.

Figs. 3a-c : Morozovella spinulosa (Cushman,1927).

3a: Umbilical side, Jaddala section, Sample No.6.

3b: Side view, Jaddala section, Sample No.6.

3c: Spiral side, Jaddala section, Sample No.6.

Figs. 4a-c: Truncorotaloides rohri (Bronnimann \& Bermudez,1953).

4a: Umbilical side, Jaddala, section, Sample No.9.

4b: Side view, Jaddala section, Sample No.7.

4c: Spiral side, Jaddala section, Sample No.7. 
PLATE (3)

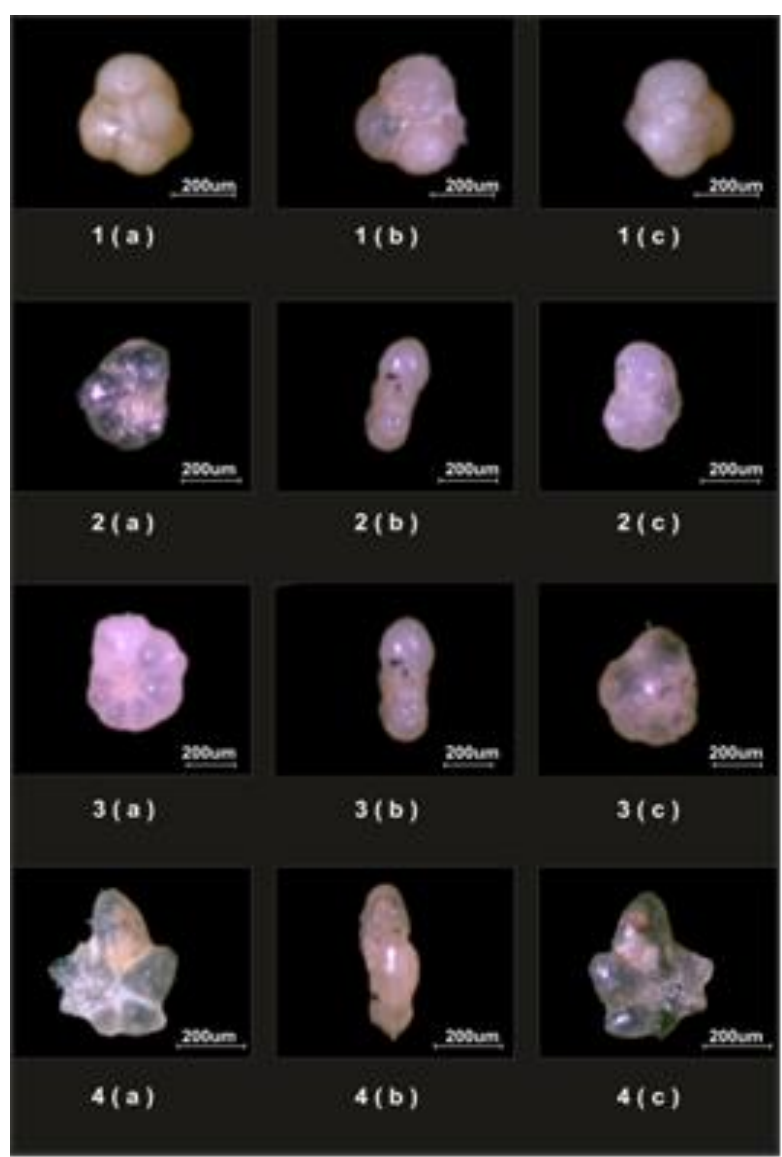

Figs. 1a-c: Globorotaloides suteri Bolli,1957 b.

1a: Umbilical side, Sinjar section, Sample No. 10.

1b: Side view, Sinjar section, Sample No. 12.

1c: Spiral side, Sinjar section, Sample No. 10.

Figs. 2a-c: Pseudohastigerina micra (Cole,1927).

2a: Umbilical side, Jaddala section, Sample No. 20.

2b: Side view, Jaddala section, Sample No. 20.

2c: Spiral side, Jaddala section, Sample No. 18.

Figs. 3a-c: Pseudohastigerina naguewichiensis Myatliuk,1950.

3a: Umbilical side, sharaf Al- deen section, Sample No. 7.

3b: Side view, sharaf Al - deen section, Sample No.7.

3c: Spiral side, sharaf Al- deen section, Sample No. 7.

Figs. 4a-c: Hantkenina dumblei Weinzierl \& Applin,1929.

4a: Umblilical side, Jaddala section, Sample No. 6.

4b: Side view, Jaddala section, Sample No. 6.

4c: Spiral side, Jaddala section, Sample No. 6. 
PLATE (4)



Figs. 1a-c: Globigerina ciperoensis ciperoensis Bolli,1957b.

1a: Umbliclical side, Sinjar section, Sample No. 11.

1b: Side view, Sinjar section, Sample No. 11.

1c: Spiral side, Sinjar section, Sample No. 11.

Figs. 2a-c: Globigerina euapertura Jenkins,1960.

2a: Umbilical side, Sinjar section, Sample No. 7.

2b: Side view, Sinjar section, Sample No. 7.

2c: Spiral side, Sinjar section Sample No. 7.

Figs. 3a-c: Globigerina ouachitaensis gnaucki Blow \& Banner,1962.

3a: Umblilical side, Jaddala section, Sample No. 20.

3b: Side view, Jaddala section, Sample No. 20.

3c: Spiral side, Jaddala section, Sample No. 20.

Figs. 4a-c: Globigerina ouachitaensis ouachitaensis Howe \& Wallace,1932.

4a: Umbilical side, Jaddala section, Sample No. 24.

4b: Side view, Jaddala section, Sample No. 24.

4c: Spiral side, Jaddala section, Sample No. 24. 